\title{
A Spirulina maxima-derived peptide inhibits HIV-1 infection in a human T cell line MT4
}

\author{
In-Seung Jang and Sun Joo Park
}

\begin{abstract}
Human immunodeficiency virus (HIV) is the causative agent of acquired immune deficiency syndrome (AIDS). AntiHIV agents targeting various steps in HIV life cycle have been developed; however, so far, no effective drugs have been found. We show here that a peptide isolated from Spirulina maxima (SM-peptide) inhibits HIV-1 infection in a human T cell line MT4. SM-peptide inhibited HIV-1 ${ }_{\text {IIIB }}$-induced cell lysis with a half-maximal inhibitory concentration $\left(\mathrm{IC}_{50}\right)$ of $0.691 \mathrm{mM}$, while its $50 \%$ cytotoxic concentration $\left(\mathrm{CC}_{50}\right)$ was greater than $1.457 \mathrm{mM}$. Furthermore, the SMpeptide inhibited the HIV-1 reverse transcriptase activity and p24 antigen production. This suggests that SM-peptide is a novel candidate peptide, which may be developed as a therapeutic agent for acquired immunodeficiency syndrome patients.
\end{abstract}

Keywords: Marine peptide, Spirulina maxima, HIV-1, AIDS

\section{Background}

Acquired immunodeficiency syndrome (AIDS) was first reported in the USA in the year 1981. Since then, the number of AIDS patients and HIV-infected persons are persistently increasing worldwide. In 2015, the World Health Organization (WHO) reported that there are over 36.7 million AIDS patients worldwide (http:// www.who.int/hiv/en/). To solve the problems resulting from AIDS, many investigations were conducted in many countries. Some well-known AIDS therapeutic agents such as $3^{\prime}$-azido-2', $3^{\prime}$-dideoxythymidine (AZT) and $2^{\prime}, 3^{\prime}$-dideoxyinosine (ddI) were approved by the Food and Drug Administration (FDA) and are now being administered to AIDS patients (Broder, 2010). However, these therapeutic agents are associated with many side effects such as anemia, neutropenia, and thrombocytopenia (Ay et al., 2013). Therefore, many research groups are being required to search for novel anti-HIV agents compatible to those of developed countries. Marine-based natural products that have chemically diverse and unique structures have received attention as sources for the development of new antiHIV agents (Vo and Kim, 2010). Marine materials such as phlorotannins, sulfated chitoolifosaccharides, sulfated

\footnotetext{
* Correspondence: parksj@pknu.ac.kr

Department of Chemistry, Pukyong National University, Busan 608-737, Republic of Korea
}

(c) The Author(s). 2016 Open Access This article is distributed under the terms of the Creative Commons Attribution 4.0 International License (http://creativecommons.org/licenses/by/4.0/), which permits unrestricted use, distribution, and reproduction in any medium, provided you give appropriate credit to the original author(s) and the source, provide a link to the Creative Commons license, and indicate if changes were made. The Creative Commons Public Domain Dedication waiver (http://creativecommons.org/publicdomain/zero/1.0/) applies to the data made available in this article, unless otherwise stated. polysaccharides, and lectin have been reported to have anti-HIV activities. Additionally, several recent studies have reported that peptides from marine organisms can act as anti-HIV agents because of their therapeutic potential in the treatment of infectious diseases (Plaza et al., 2007 and 2009). In this regard, we examined antiHIV activities of our previously isolated peptides from several marine organisms and found that a peptide from Spirulina maxima (SM-peptide) inhibits HIV-1 infection in human T cell line MT4. SM-peptide inhibited HIV$1_{\text {IIIB }}$-induced cell lysis, p24 antigen production, and HIV-1 reverse transcriptase.

\section{Methods \\ Materials and chemicals}

We purified the $S$. maxima peptide as reported by Vo et al. (2014). The purity of the peptide was $>98 \%$ according to RP-HPLC assessment and $N$-terminal sequence analysis. The amino acid sequence of the final purified peptide was determined to be LDAVNR by electrospray ionization mass spectrometry (ESI/MS) (Vo et al., 2014).

MTT (3-(4,5-dimethylthiazol-2-yl)-2,5-diphenyltetrazolium bromide) was purchased from Sigma-Aldrich (St. Louis, USA). DMSO was obtained from Amresco (Solon, USA). Specific antibodies for western blot were purchased from R\&D systems (NE Minneapolis, USA) and Santa Cruz Biotechnology (Dallas, USA). 


\section{Cells and viruses}

MT4 and H9/HIV-1 $1_{\text {IIIB }}$ cell lines were obtained from the NIH AIDS Reagent Program (Germantown, USA). All cell lines were cultured in RPMI-1640 (Thermo Scientific, USA) supplemented with 10\% heat-inactivated FBS (Thermo Scientific, USA), $50 \mu \mathrm{g}$ of streptomycin, and $50 \mathrm{U}$ of penicillin per milliliter (PAA, USA) in $5 \% \mathrm{CO}_{2}$ containing air at $37{ }^{\circ} \mathrm{C}$. Cells were passaged every 24 days and maintained at a cell density of $5 \times 10^{5}-1 \times$ $10^{6}$ cells $/ \mathrm{ml}$. HIV-1 $1_{\text {IIIB }}$ viral particles were obtained from the supernatants of $\mathrm{H} 9 / \mathrm{HIV}-1_{\text {IIIB }}$ cell line. The viruses were stored at $-80{ }^{\circ} \mathrm{C}$ until use. Viral titer was determined by 24 assay performed using MT4 cells. Viral titer was expressed as TCID $_{50}$.

\section{Cell viability assay}

MT4 cells were seeded in a 96-well plate at $2 \times 10^{4}$ cells/ well with RPMI-1640 medium containing $10 \%$ FBS. After $24 \mathrm{~h}$, the cells were treated with SM-peptide and incubated further for $24 \mathrm{~h}$ at $37{ }^{\circ} \mathrm{C}$. Twenty-four hours later, fresh RPMI-1640 medium with $10 \%$ FBS was added to each well. After $84 \mathrm{~h}, 20 \mu \mathrm{l}$ of MTT solution (final concentration of $0.5 \mathrm{mg} / \mathrm{ml}$ ) was added to each well and the plate was incubated for $4 \mathrm{~h}$ at $37^{\circ} \mathrm{C}$. Finally, $200 \mu \mathrm{l}$ of DMSO was added to dissolve the purple formazan. The amount of formazan was determined by measuring absorbance at $595 \mathrm{~nm}$ using a microplate reader (Filter Max 5, Molecular Devices).

\section{Cell lysis effect by HIV-1 $1_{\text {IIIB }}$ infection}

To determine the anti-HIV activity of SM-peptide on HIV-infected MT4 cells, MTT assay was performed. MT4 cells were seeded in duplicate in a 96-well plate at a density of $2 \times 10^{4}$ cells/well. After $24 \mathrm{~h}$, stock virus of HIV-1 $1_{\text {IIIB }}$ was added to each well at 50 TCID $_{50}$ along with the different concentrations of SM-peptide. The plate was incubated for $72 \mathrm{~h}$ at $37{ }^{\circ} \mathrm{C}$ with $5 \% \mathrm{CO}_{2}$. Cell viability was determined by MTT assay.

\section{p24 antigen production assay}

MT4 cells $\left(2 \times 10^{4}\right.$ cells/well $)$ were seeded in a plate. After 1 day, the MT4 cells were treated with SM-peptide and infected with $50 \mathrm{TCID}_{50}$ of HIV-1 ${ }_{\text {IIIB }}$. The plate was incubated for $72 \mathrm{~h}$. The supernatant was harvested by centrifugation. In order to determine the amount of HIV, Lenti-X p24 rapid titer kit was used according to the manufacturer's protocol (Clontech, USA).

\section{Reverse transcriptase activity assay}

The activity of $\mathrm{HIV}-1$ reverse transcriptase in the virus supernatant was determined by using a reverse transcriptase assay kit (Roche, Germany) according to the manufacturer's protocol. Briefly, a reaction mixture containing poly $(\mathrm{A}) \times \operatorname{oligo}(\mathrm{dT})_{15}$ was added to the virus supernatant and incubated for $4 \mathrm{~h}$ at $37{ }^{\circ} \mathrm{C}$. Two hundred microliters of anti-DIG-POD and ABTS were then added stepwise. The virus supernatant was incubated at room temperature until the color development was sufficient for detection. The absorbance of the virus supernatant was measured using a microplate reader at $405 \mathrm{~nm}$.

\section{Statistical analysis}

Data were analyzed using the InStat statistics program (GraphPad Software, Inc., San Diego, CA, USA). Statistical comparisons were performed using one-way analysis of variance (ANOVA) with Duncan's multiple comparisons test. Differences were considered significant at $p<0.05$.

\section{Results}

To identify natural peptides with anti-HIV-1 activity, we screened peptides from several marine organisms for their anti-HIV-1 activities. In this study, we showed that a peptide isolated from S. maxima, SM-peptide, has an anti-HIV-1 activity. The peptide was previously purified from enzymatic hydrolysates of $S$. maxima, and its sequence is LDAVNR with molecular mass of $686.37 \mathrm{Da}$ (Vo et al., 2014).

We first examined the cytotoxicity of SM-peptide in human MT4 T cells. The MT4 cells were treated with 0-1 $\mathrm{mg} / \mathrm{ml} \mathrm{SM-peptide} \mathrm{for} 72 \mathrm{~h}$, and the viability of MT4 cells was measured by a formazan-based MTT assay. Figure 1 shows that the SM-peptide did not affect the viability of MT4 cells at concentrations below $1 \mathrm{mg} /$ $\mathrm{ml}(1.457 \mathrm{mM})$. Next, the protective activity of the SMpeptide on $\mathrm{HIV}-1_{\text {IIIB }}$-induced cell lysis was also investigated by MTT assay (Fig. 2). HIV-1 ${ }_{\text {IIIB }}$-induced lysis of

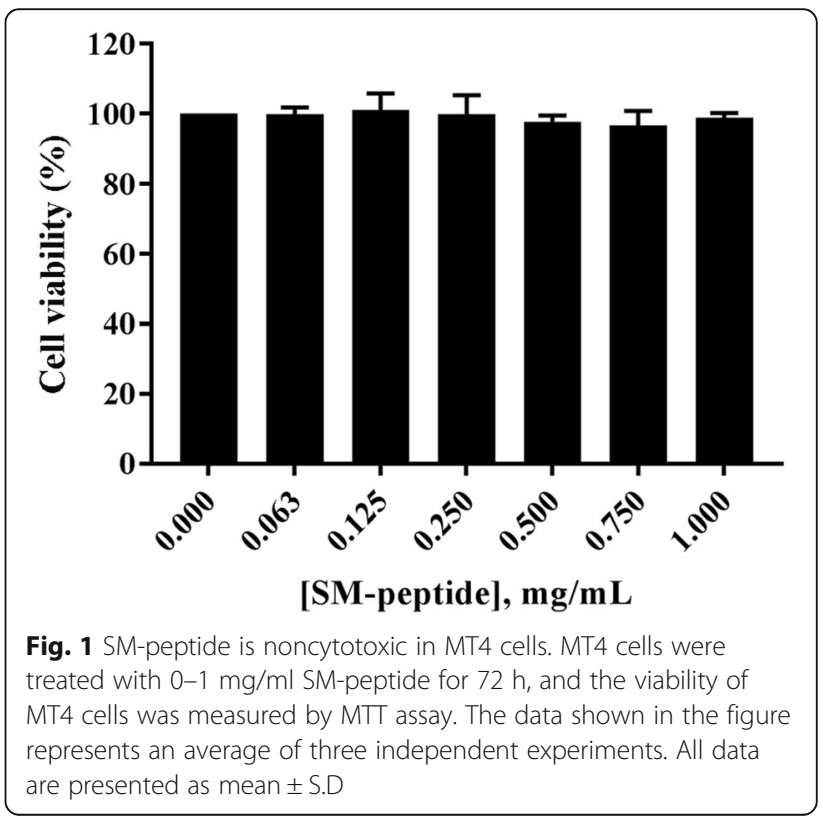




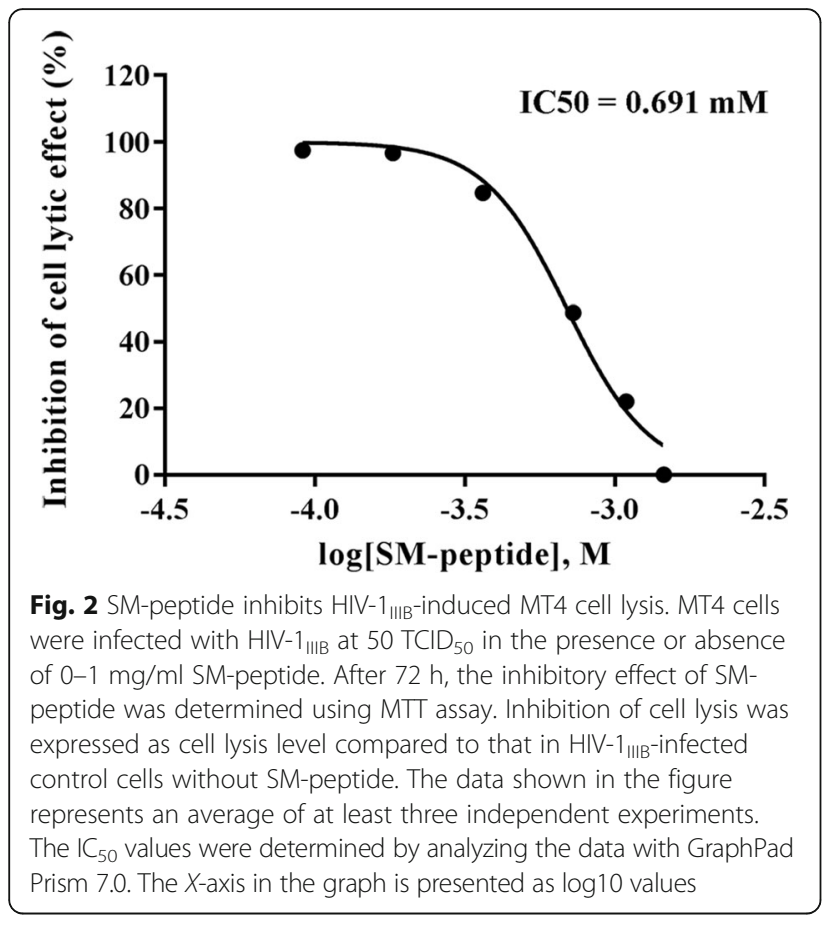

MT4 cells was decreased by SM-peptide. $\mathrm{IC}_{50}$ of SMpeptide against anti-HIV- $1_{\text {IIIB }}$ infection was assessed to be $0.475 \mathrm{mg} / \mathrm{ml}(0.691 \mathrm{mM})$.

The anti-HIV-1 activity of SM-peptide was further examined by determining its effect on HIV-1 reverse transcriptase (RT) activity. RT activity is used by the HIV-1 retrovirus to convert single-strand genomic RNA into double-strand cDNA which can integrate into the host genome, potentially generating a long-term infection. SMpeptide was found to inhibit HIV-1 $1_{\text {IIIB }}$-induced RT activation in MT4 cells (Fig. 3). SM-peptide $(0.75 \mathrm{mg} / \mathrm{ml}$,

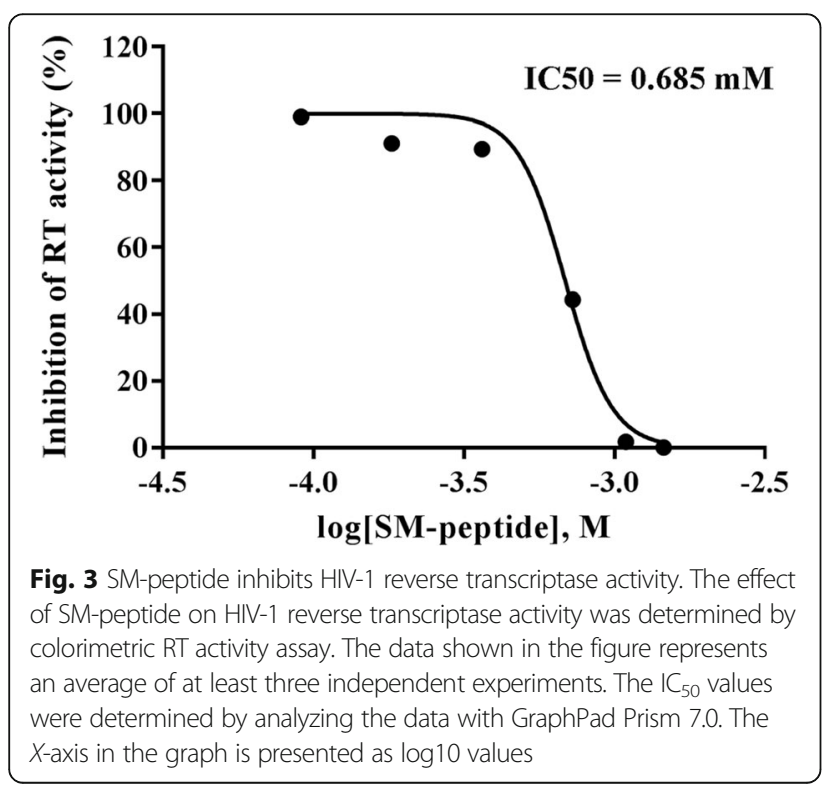

$1.093 \mathrm{mM}$ ) inhibited the RT activity in HIV-1 ${ }_{\text {IIIB }}$-infected cells by approximately $90 \%$ as compared to control (no peptide). In addition, we examined the effect of SMpeptide on HIV-1 p24 antigen production. p24 antigen is a structural protein that makes up most of the HIV viral core. High levels of p24 are present in the blood serum of newly infected individuals during the short period between infection and seroconversion, making p24 antigen assays useful in diagnosing primary HIV infection. As shown in Fig. 4, SM-peptide $(0.75 \mathrm{mg} / \mathrm{ml}, 1.093 \mathrm{mM})$ inhibited the HIV-1 $1_{\text {IIIB }}$ p 24 antigen production by more than $95 \%$. The inhibitory effect of SM-peptide on p24 protein production was also confirmed by western blot analysis of cell lysates with anti-p24 antibody. SM-peptide treatment decreased the HIV-1 p24 production significantly in cell lysates.

Taken together, these results suggest that marine natural SM-peptide inhibits HIV-1 infection by suppressing HIV-1 $1_{\text {IIIB }}$-induced cell lysis, HIV-1 reverse transcriptase activity, and p24 antigen production.

\section{Discussion}

HIV, the causative agent of AIDS, is one of the hottest areas of medical research today. Because of the high prevalence and mortality associated with HIV infections, many researchers have focused on finding ways to fight the infection and improve the life span of HIV-infected individuals. So far, there are five major classes of antiHIV-1 drugs that targeted distinct steps in the HIV life cycle: reverse transcriptase inhibitors, protease inhibitors, fusion inhibitors, integrase inhibitors, and multidrug combinations (Lifson et al., 2016). These drugs, though effective, do not cure HIV/AIDS. People with HIV infection still have the virus in their bodies and can spread the virus to others. Therefore, to improve the therapeutic potential of these medicines, identification of additional and suitably modified novel drug candidates is necessary (Migueles and Connors, 2015).

Numerous recent studies have reported that marine peptides from marine sponges may be used as anti-HIV agents (Vo and Kim, 2010; Ngo et al., 2012). The marine peptides have been found to mainly inhibit viral entry through membrane fusion (Plaza et al., 2007 and 2009; Zampella et al., 2008; Oku et al., 2004). The present study showed that a peptide isolated from $S$. maxima (SM-peptide) is noncytotoxic and inhibits HIV- $1_{\text {IIIB }}$-induced cell lysis, reverse transcriptase activity, and viral p24 antigen production. SM-peptide was isolated and reported to downregulate the IgE receptor-mediated mast cell activation by Vo et al. (2014). HIV-induced immune dysfunction has been known to increase the likelihood of developing allergic and other immune-mediated diseases in patients. Antiretroviral therapy is associated with reconstitution of the immune system function. 


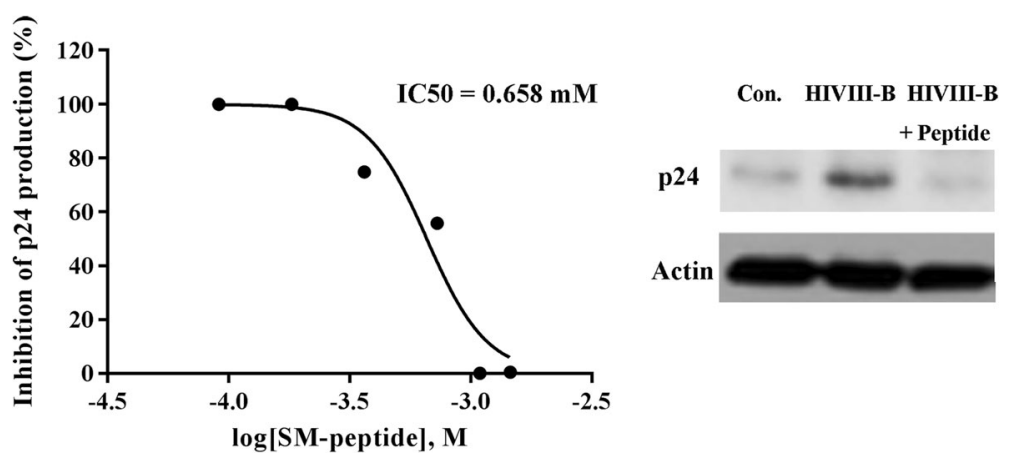

Fig. 4 SM-peptide inhibits HIV-1 ${ }_{\text {IIIB }}$-induced p24 antigen production. MT4 cells were infected with HIV- $1_{\text {IIIB }}$ of 50 TCID 50 in the presence or absence of $0-1 \mathrm{mg} / \mathrm{ml} \mathrm{SM-peptide.} \mathrm{The} \mathrm{amount} \mathrm{of} \mathrm{p24} \mathrm{production} \mathrm{was} \mathrm{determined} \mathrm{by} \mathrm{p24} \mathrm{antigen} \mathrm{capture} \mathrm{ELISA.} \mathrm{The} \mathrm{data} \mathrm{shown} \mathrm{in} \mathrm{the} \mathrm{figure} \mathrm{represents}$ an average of at least three independent experiments. The $I C_{50}$ values were determined by analyzing the data with GraphPad Prism 7.0. The $X$-axis in the graph is presented as $\log 10$ values. Cellular p24 proteins were also analyzed by western blot analysis. MT4 cells were infected with HIV-1 ${ }_{\text {IIIB }}$ of $50 \mathrm{TCID}_{50}$ in the presence or absence of $1 \mathrm{mg} / \mathrm{ml} \mathrm{SM}$-peptide

Therefore, SM-peptide may contribute to restore the body's defense mechanism against infectious immune system disorder.

We tried to generate several derivatives of synthetic peptide to identify the specific amino acid residues responsible for the anti-HIV-1 activity of SM-peptide; however, we were unable to perform experiments in cells because of the insolubility of the synthetic peptides. Thus, the simulation methods such as the molecular docking approach may be useful to determine the mechanism of SM-peptide action on HIV-1 infection. In conclusion, SM-peptide is a novel and safe peptide with HIV-1 inhibitory activity and may be a promising candidate for the design of novel HIV/AIDS drugs.

\section{Conclusions}

We demonstrated that a peptide from S. maxima inhibits HIV-1 infection in a human T cell line MT4. SMpeptide exhibits inhibitory activity on HIV-1 ${ }_{\text {IIIB }}$-induced lysis, p24 antigen production, and HIV-1 reverse transcriptase at noncytotoxic concentrations. This finding suggests that the marine peptide SM-peptide is a novel candidate peptide, which may be developed as a therapeutic agent for AIDS patients.

\section{Abbreviations \\ AIDS: Acquired immune deficiency syndrome; AZT: 3'-Azido-2', 3'- dideoxythymidine; $\mathrm{CC}_{50}$ : 50\% Cytotoxic concentration; ddl: 2',3'- Dideoxyinosine; ESI/MS: Electrospray ionization mass spectrometry; FBS: Fetal bovine serum; HIV: Human immunodeficiency virus; $\mathrm{IC}_{50}$ : Half-maximal inhibitory concentration; MTT: 3-(4,5-Dimethyl-2-yl)-2,5-diphenyltetrazolium bromide; RT: Reverse transcriptase; SM-peptide: Peptide isolated from Spirulina maxima; WHO: World Health Organization}

\section{Acknowledgements}

This study was supported by the Basic Science Research Program from the National Research Foundation of Korea (NRF), funded by the Ministry of Education, Science and Technology (2012R1A1A2041500) and (2015R1D1A3A01018506).

\section{Funding}

This study was funded by a grant from the Basic Science Research Program from the National Research Foundation of Korea (NRF), funded by the Ministry of Education, Science and Technology (2012R1A1A2041500) and (2015R1D1A3A01018506).

\section{Availability of data and materials}

All datasets generated and/or analyzed during the current study are available from the corresponding author on reasonable request.

\section{Authors' contributions}

ISJ designed and carried out the experiments. SJP interpreted the results and wrote the manuscript. Both of the authors read and approved the final manuscript.

\section{Competing interests}

The authors declare that they have no competing interests.

\section{Consent for publication}

Not applicable.

Ethics approval and consent to participate

Not applicable.

Received: 23 August 2016 Accepted: 5 November 2016

Published online: 11 November 2016

\section{References}

Ay E, Banati F, Mezei M, Bakos A, Niller HH, Buzas K, et al. Epigenetics of HIV infection: promising research areas and implications for therapy. AIDS Rev. 2013:15:181-8.

Broder S. The development of antiretroviral therapy and its impact on the HIV-1/ AIDS pandemic. Antiviral Res. 2010:85:1-18.

Lifson MA, Ozen MO, Inci F, Wang S, Inan H, Baday M, et al. Advances in biosensing strategies for HIV-1 detection, diagnosis, and therapeutic monitoring. Adv Drug Deliv Rev. 2016;103:90-104.

Migueles SA, Connors M. Success and failure of the cellular immune response against HIV-1. Nat Immunol. 2015;16:563-70.

Ngo DH, Vo TS, Ngo DN, Wijesekara I, Kim SK. Biological activities and potential health benefits of bioactive peptides derived from marine organisms. Int J Biol Macromol. 2012;51:378-83.

Oku N, Gustafson KR, Cartner LK, Wilson JA, Shigematsu N, Hess S, et al. Neamphamide A, a new HIV-inhibitory depsipeptide from the Papua New Guinea marine sponge Neamphius huxleyi. J Nat Prod. 2004;67:1407-11.

Plaza A, Gustchina E, Baker HL, Kelly M, Bewley CA. Mirabamides A-D, depsipeptides from the sponge Siliquariaspongia mirabilis that inhibit HIVfusion. J Nat Prod. 2007;70:1753-60. 
Plaza A, Bifulco G, Keffer JL, Lloyd JR, Baker HL, Bewley CA. Celebesides A-C and theopapuamides $B-D$, depsipeptides from an Indonesian sponge that inhibit HIV-1 entry. J Org Chem. 2009;74:504-12.

Vo TS, Kim SK. Potential anti-HIV agents from marine resources: an overview. Mar Drugs. 2010;8:2871-92.

Vo TS, Ngo DH, Kang KH, Park SJ, Kim SK. The role of peptides derived from Spirulina maxima in downregulation of FcepsilonRl-mediated allergic responses. Mol Nutr Food Res. 2014;58:2226-34.

Zampella A, Sepe V, Luciano P, Bellotta F, Monti MC, D'Auria MV, et al. Homophymine A, an anti-HIV cyclodepsipeptide from the sponge Homophymia sp. J Org Chem. 2008;73:5319-27.

Submit your next manuscript to BioMed Central and we will help you at every step:

- We accept pre-submission inquiries

- Our selector tool helps you to find the most relevant journal

- We provide round the clock customer support

- Convenient online submission

- Thorough peer review

- Inclusion in PubMed and all major indexing services

- Maximum visibility for your research

Submit your manuscript at www.biomedcentral.com/submit
Biomed Central 